\title{
ELT STUDENT TEACHER IDENTITY CONSTRUCTION: EXPLORING TEACHER ROLES AND DOMAINS OF EXPERTISE
}

\author{
Nafiye Cigdem Aktekin \\ Acıbadem Mehmet Ali Aydinlar University, Turkey \\ Email: nafiye.aktekin@acibadem.edu.tr \\ Hatice Celebi \\ University of Massachusetts Amherst, the USA \\ Email: haticecelebi79@gmail.com
}

\begin{abstract}
In this study, we direct our focus to identity construction in an English language teaching (ELT) teacher education program. We explore the teacher roles in which student teachers are struggling to position themselves comfortably and the teacher expertise domains (subject matter, didactics, and pedagogy) that they are dedicating themselves to improving. To address our research focus, we have collected reflections and survey responses from 18 student teachers in an ELT education department. Our findings indicate that ELT student teachers find it difficult to position themselves as experts in and about the English language and that they feel a need to be equipped with expertise first and foremost in the subject matter, and then in didactics, followed by pedagogy. These results imply that in ELT teacher education, certain language ideologies are still prevalent and need to be dealt with by teacher educators for transformative outcomes in education.
\end{abstract}

DOI: $10.26858 /$ ijole.v4i2.10655

Keywords: ELT, Identity, Teacher education, Student Teacher Reflection, Teacher Expertise

\section{INTRODUCTION}

Providing opportunities for student teachers to inquire about and engage in teacher identity construction is crucial since this catalyzes a process for them "to become members of particular communities, such as school" (Vetter, Hartman, \& Reynolds, 2016, p. 309). It has been maintained that a deeper understanding of identity is important for designing teacher education programs and that identity work needs "overt attention" (Beauchamp \& Thomas, 2006, 2009; Thomas \& Beauchamp, 2007). One way of giving overt attention to identity construction is reflective practice. Reflective practice resonates with the notion that identity is a discursive and performative phenomenon (Benwell \& Stokoe, 2006; Butler, 1990; Gergen, 1991) and not pre-discursive or reflective of an essential identity or true, inner self (Benwell \& Stokoe, 2006). As a result of this conceptualization of identity, reflective practice is considered to have emerged from philosophical theories on the role of language as "not simply reflecting or representing the reality but actively constructing it," meaning that "...identity manifests in discourse" (La Pointe, 2010, p. 2). In our paper, reflective practice took two forms for the English language teaching (ELT) student teachers who participated in our study. One form was through writing reflective journal entries and the other was through giving responses to a survey that the student teachers completed as they explored their identity construction in terms of teacher expertise domains.

Student teachers construct knowledge and identity through reflective practice as they gain a broader understanding of their personal beliefs and actions as well as what influences their learning. However, reflection, i.e., the conscious effort of exploring an issue and seeking a conclusion through an individual's purposeful engagement, as presented by Dewey (1933) and Schön (1983), has been reported to be purposefully avoided by teachers (Gelter, 
2003). This points to why it is important for student teachers to practice reflection from an early stage. Ladson-Billings (1995) points out that teachers are not fully able to assess their beliefs, actions, and the social contexts within which they execute their beliefs. Further, as Banks (1999) states, "[t]eachers cannot transform schools until they transform themselves" (p. xi). In ELT, this type of critical awareness is crucial for transformative education so that ELT teachers can negotiate more democratic ideologies about language, such as bilingual spaces that do not conform to monolingual norms (Canagarajah, 2013; Garcia, 2009).

With our study, we aim to highlight that student teachers become more aware of who they are as teachers as they reflect upon how they position themselves in relation to their professional identity. We maintain that through the early practices of identity construction, teachers can become more aware of the multiple dimensions of "how to be," "how to act," and "how to understand" (Sachs, 2005, p. 15) in the teaching profession in order to be better able to assess their beliefs and actions as well as the social contexts in which they execute their beliefs so that they can challenge monoglossic language ideologies through their empowered identities.

\section{LITERATURE REVIEW}

Teacher identity is a framework within which teachers build their own ideas about the teaching profession (Sachs, 2005). How teacher identity is constructed and how it can be used to explore teacher development have gained emphasis in the literature over the years (Olsen, 2008; Riopel, 2006; Sachs, 2005). Identity construction has been scrutinized through the exploration of a variety of sources such as personal experience, self-awareness, self-observation and reflective teaching, and constructing "selves" (e.g., Bailey, Curtis, \& Nunan, 2001; Bukor, 2015; Cattley, 2007; Lamote \& Engels, 2010). According to Gee (2000), identity is "[b]eing recognized as a certain 'kind of person,' in a given context" (p. 99).
Identity is shaped with the conditions and through the opportunities supplied by the situational atmosphere (Bauman, 1996; Holland \& Lave, 2001; Roth, 2004) and "serves as the repository of particular experiences in classrooms and schools, the site of thoughts, attitudes, emotions, beliefs and values" (Zembylas, 2003, p. 107). As such, the construction of teacher identity is an ongoing process that happens through a continuous and changing process of transformation (Akkerman \& Meijer, 2011; Alsup, 2006; Varghese, Morgan, Johnston, \& Johnson, 2005).

Stenberg, Karlsson, Pitkaniemi, and Maaranen (2014) point out that exploring the "starting point" of student teachers' teacher identity is especially important "to support their professional development in meaningful and effective ways during their teacher education" (p. 205). Studies suggest that there is a great need to support emerging teacher identities through the early integration of students into teaching so that they do not feel "lost," but instead feel more committed to teaching (Löfström, PoomValickis, Hannula, \& Mathews, 2010; Rots, Aelterman, Vlerick, \& Vermeulen, 2007).

In this study, we asked ELT student teachers to reflect on six main teacher roles: facilitator, assessor, planner, resource developer, information provider, and role model (Harden \& Crosby, 2000) to see how they position themselves within the personalprofessional I-positions, as in "I as a facilitator," "I as an learning as an assessor," "I as a planner," and so on (see Figure 1); we also investigated where the student teachers feel they stand in terms of the teacher expertise domains in the first years of their education program and where they want to stand in the future as teachers.

\section{Teacher Identity and Roles}

Stenberg et al. (2014) approach teacher identity through the lens of two models, that of James (1890) and Bakhtin (1973) and that of the dialogical point of view of the "self" that Hermans, Kempen, and Van Loon (1992) put forward. The self is "a dynamic 
array of relatively autonomous $I$-positions" (p. 205), and each I-position (e.g., "I as a pedagogue," "I as a subject matter expert," or "I as a member of society") has "its own voice" that comes out through dialogues with contexts and relationships. A similar concept that emphasizes teacher identity formation through position-taking is "the positioning theory" (van Langenhove \& Harré, 1999). Positioning happens in the discursive process of locating selves in conversations interactively (i.e., when a person positions another person) or reflexively (i.e., when a person positions himself or herself) (Davies \& Harré, 1990; Vetter et al., 2016). In other words, identities are constituted and given meaning in discourse within social and cultural practices (Gergen, 1991).

One complex issue underlying identity revolves around the dimensions of the personal and the professional. The "personal" can be understood as understanding of the self, and the "professional" can be defined as the notion of the self within an outside context, such as a classroom or a school (Beauchamp \& Thomas, 2009). A number of authors take a combined view and perceive the self as a key to the notion of the professional (see Borich, 1999; Day, Kington, Stobart, \& Sammons, 2006; Freese, 2006; Hamachek, 1999; Lipka \& Brinthaupt, 1999). In this study, we combine the personal and self with the professional by using teacher roles (Harden \& Crosby, 2000) as a tool for the students to reflect so that their $I$ positions can find their voices through position-taking in reflection.

\section{Domains of ELT Teacher Expertise}

According to the definition of Beijaard, Verloop, and Vermunt (2000), teachers' expertise falls under three headings: subject matter, didactics, and pedagogy. Subject matter has a different knowledge base depending on the field. In its simplest sense, for ELT, knowledge of the subfields of the linguistics of English such as semantics, syntax, and phonology make up the subject matter knowledge base. The domain pedagogy covers issues such as students' learning processes, their activities, and their own responsibility for learning as well as an understanding of human thought, behavior, and communication. Didactics includes concerns such as teaching-learning processes, which can include planning, execution and assessment, and evaluation of teaching activities.

It has been strongly suggested that university teachers examine their teaching practices so that they not only facilitate teacher knowledge as part of subject expertise but also so that they can facilitate pedagogical teacher expertise: "[s]tudents may become discouraged if the only teacher expert role they are exposed to in the university is that of a subject matter expert, and simultaneously they are lacking a connection to school as a working environment" (Löfström et al., 2010, p. 182). Teachers are experts in their subject matter, but if delivery of the subject matter becomes the sole target, pedagogical issues such as student learning processes, their activities, and their own responsibility for learning as well as an understanding of human thought, behavior, and communication might be overlooked (Beijaard et al., 2000; Löfström et al., 2010). Therefore, an exploration of teacher professional identity construction can also be used as a tool to more effectively and efficiently plan teaching around teacher expertise domains.

\section{Actual and Designated Identities}

In this study, while we aim to explore early ELT teacher identity construction in relation to teacher roles and domains of expertise, we work with two operational constructs, actual and designated identities. We have borrowed these two constructs from the "narrative identity theory" formulated by Sfard and Prusak (2005). Within the framework of the narrative theory, Sfard and Prusak (2005) explain that a person's narratives fall into two categories: 1) actual, that is, consisting of narratives about the actual state of affairs, and 2) designated, or consisting of narratives presenting a state expected to be the case in the future. "I am a 
good driver" and "I have to be a better person" (p. 18) are narrative examples that Sfard and Prusak (2005) give for actual and designated identities (respectively).

Actual and designated identities have been echoed by various scholars in relation to different theories (Dörnyei, 2009; Higgins, 1987, 1998; Lauriala \& Kukkonen, 2005; Rodgers \& Scott, 2008; Sfard \& Prusak, 2005). For instance, the notions of "selfconcept" and "self-guide" (Higgins, 1987), and later on, the "ideal" and "ought" selves (Higgins, 1998) resonate with the notions of actual and designated identities. Dörnyei (2009) proposes that "people are motivated to reach a condition where their self-concept matches their personally relevant self-guides (emphasis added)" (p. 18) and that they have a desire to reduce the gap between their actual condition and the future self-guides that they have designated themselves as. Along similar lines, in our study, the terms "actual identities" and "designated identities" imply the existence of a zone of proximal development (Vygotsky, 1998) through which teachers' professional identities are constructed.

\section{Language Ideologies and ELT Teachers}

Piller (2015) defines language ideologies as "beliefs about language" and "feelings about language" (p. 2). She emphasizes that exploring language ideologies is important because "[t]hey provide a link between linguistic and social forms and structures" (p. 2). English language teachers are agents of language ideologies since they are overt or covert providers of understandings of language and social interaction. Monoglossic language ideologies assume that "legitimate linguistic practices are only those enacted by monolinguals" (Garcia, 2009, p. 115). In other words, some uses of linguistic resources index higher sociolinguistic scales as they "scale up" or "lift a particular topic or moment" (Mortimer, 2016, p. 350) to "a higher level of relevance, truth, validity or value" (Blommaert, 2007, p. 6). With monoglossic ideologies, concepts such as intralanguage variation, hybrid language use and multiplicity, and dynamism of identities (Irvine \& Gal, 2000) are erased by monoglossic concepts such as "mother tongue" and "second language" (Garcia, 2009; Skutnabb-Kangas, 1981). In the context of our study, for the ELT student teachers, English is not a "mother tongue" or a "second language" since it is not one of the official languages of the country. In other words, language ideologies are at work in ways that Park (2012) points out as occurring with non-native English-speaking teachers coming from outer circle countries and their struggles with identity construction. As such, we theorize that an acknowledgement of language ideologies in explorations of teacher identity in ELT teacher education is essential, and we acknowledge the presence of various language ideologies at work in our research context.

\section{METHOD}

We had two aims in our study. First, we wanted to encourage the ELT student teachers to reflect upon the teacher roles in which they most or least comfortably position themselves. This was to bring out findings about whether there was a common role that the ELT student teachers were struggling with while positioning themselves. To achieve this aim, we prompted second-year student teachers to reflect on the teacher roles they adopted while completing the structured teaching practices we pre-designed for them. Second, we aimed to investigate whether there was a common domain of teacher expertise that the ELT student teachers felt the greatest need to develop themselves in so that we could reach conclusions about which domain was at the heart of their identity construction. We used two operational terms - actual identities and designated identities - and asked the student teachers in a survey to describe how confident they felt in the three domains of teacher expertise: subject matter, pedagogy, and didactics (Beijaard et al., 2000). In this way, we were able to deduce which common domain of expertise the student teachers were 
struggling with as they constructed their teacher identities.

Our research was motivated on the grounds that teacher knowledge is at the heart of teacher identity (Connelly \& Clandinin, 1988) and that reflective practice as a learning tool is vital in an educator's life (Van Manen, 1995). Reflection is an intentional, dynamic process that allows improvement in one's actions, abilities, and knowledge (Dewey, 1933; Schön, 1983). We explored the following two questions

- Is there a common role that the ELT student teachers believe they are struggling with while positioning themselves?

- Is there a common domain of expertise (pedagogy, subject matter, and didactics) in which ELT student teachers report feeling the need to develop themselves the most?

\section{Context of the Study}

The study was carried out at the Faculty of Education, Department of English Language Teaching at a private university in Turkey in the fall semester of the 2016-2017 academic year. Although English is not an official language of Turkey, there is a high level of demand for graduates of ELT programs in the country. At the tertiary level alone in 2013, for instance, it was stated that there were 164 universities in Turkey with more than $75 \%$ of their programs taught in English (Ölçme, Seçme ve Yerleştirme Merkezi, 2013), and $18.5 \%$ of all bachelor degree programs were reported to be carried out in English (Arik \& Arik, 2014). In the European Credit Transfer and Accumulation System (ECTS), student teachers of ELT complete 240 ECTS in 4 academic years. The first two years of the program are heavily theoretical while the two last years include courses at partner schools that target teaching practice. The university the study was conducted at has been implementing a model called the "University within School" (UwS) since 2014-2015 teaching year. It suggests that teachers be educated through partnership between universities and schools. It combines two models of professional education: one is the traditional "apprenticeship-internship-master" model, which is completely practice-based; the other is the current model of teacher education, which is heavily theoretical. UwS is based on both "theoretical knowledge" and "workplace experience. To this end, the students in this program start micro-teaching activities and observing mentor teachers at different levels in the schools beginning from the first year of their education.

\section{Participants}

There were 18 student teachers who participated in this study. Before the study was conducted, Ethics Committee approval was received from the university where the study took place, and the participants' informed consent documents were collected at the beginning of the study. The participant student teachers were second-year ELT students. Thirteen of them were female, and five were male. Their ages ranged from 18 to 20 years old. The data collection was integrated into the curriculum as voluntary work, with the encouragement that student teachers would benefit from it professionally. Their teaching experience was one-to-one mentoring of primary school students in a state school for one hour a week for 15 weeks as part of one of their courses and observing mentor teachers on similar terms. Their familiarity and comfort with the concept and practice of writing reflective journal entries was limited. For this reason, in the first four weeks of the course (once every two weeks), we formed group discussions during which the student teachers went over the teaching practice experiences that they had during those two particular weeks and exchanged ideas about the roles they thought they adopted before they wrote their reflection entries. The reflection entries were written individually.

\section{Data Collection}

Two types of data collection tools were used in the study: reflective journal entries and a survey. The student teachers wrote 
reflection entries every two weeks, taking into consideration their teaching practice experiences during that particular two-week period. The prompt we used to get the student teachers to write their reflection entries was generic in nature, such as the following: "Considering the teaching practice experiences you have had for the last two weeks, reflect on the teacher roles (facilitator, assessor, planner, resource developer, information provider, and role model) you think you adopted. How do you describe yourself in those roles? Explain and discuss." A week before the first reflection, we organized an hour-long focus group meeting in which we familiarized the student teachers with the six teacher roles (Harden \& Crosby, 2000). For this, we used an archived video-recorded ELT lesson one of the researchers had archived from her own teaching to college students. In this session, students watched the video and identified the roles the teacher took as she taught. We shared Figure 1 with the students as a visual that they could peruse while they reflected.

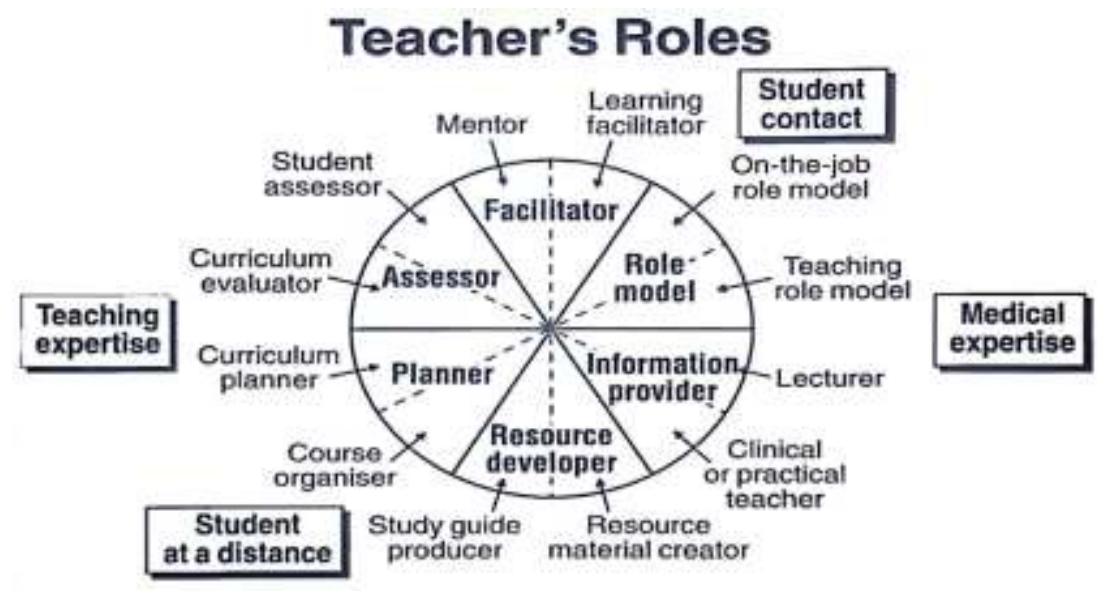

Figure 1. Teacher Roles from Harden \& Crosby (2000)

We developed our second tool, the survey, by modifying the indicators of teacher expertise domains that Voss, Kunter, and Baumert (2011), König, Blömeke, Paine, Schmidt, and Hsieh (2011), and Beijaard et al. (2000) propose. In our survey, there were thirty value statements (e.g., "I feel confident in using the given quantity of instructional time in classroom," "I believe I can treat my students positively, openly, and with respect"). The first ten items concerned pedagogy, the second ten concerned subject matter, and the last ten concerned didactics; the questions were categorized as teacher expertise domains. To get the student teachers familiar with actual and designated identities, they were provided with reading materials and discussion materials on ELT teacher identity construction over the course of a week (3 teaching hours) of classroom teaching supported by an online learning management system outside the classroom. On the survey, student teachers marked a value from 1 to 5 on descriptive statements about their "actual identity," describing by implication how confident they felt at that moment in their actual state, and they gave another value, again from 1 to 5 , for their "designated identity," describing by implication how much they wanted to improve themselves in relation to the statement they were giving a value to.

\section{Data Analysis}

We conducted two-cycle coding (Saldaña, 2013) on the reflection entries. For the first cycle of coding, we used the six teacher roles: facilitator, assessor, planner, resource developer, information provider, and role model (Harden \& Crosby, 2000) as our provisional codes (Creswell, 2012). We coded each student teacher reflection 
according to the six roles they considered themselves to have adopted during the teaching activities they had been assigned to complete. In this cycle, we took a "lumping" (Saldaña, 2013, p. 22) versus a "splitter" coding approach and worked with broader lines instead of a line-by-line detailed approach (Bernard, 2011, p. 379). The provisional codes (the six teacher roles) provided us with a holistic viewpoint of the data. For our second cycle, after coding each student's entry for the six teacher roles, we carried out magnitude coding (Saldaña, 2013) to explore the evaluative direction (Fielding, 2008) of the comments the student teachers used to describe their experiences with the roles they adopted, as either struggling (STR) or comfortable (COM). This type of coding allowed us to find the specific roles in which they predominantly positioned themselves as "struggling" because we could quantify the number of comments indicating STR and COM in reference to the roles and visually represent them in Table 1. We took notes on the recurring themes, which are reported in the findings section. In terms of the survey, 18 ELT student teachers' responses were analyzed using SPSS 17.0 (SPSS Inc., Chicago). The mean values of each domain for actual and designated identities were calculated and compared. The results are visually represented in Table 2.

\section{FINDINGS}

As a result of our analysis of ELT student teacher reflective journal entries, we found that there were three common teacher roles-information provider, resource developer, and assessor-within which our ELT student teachers struggled to position themselves. The roles and the percentage of comments as indicators of their struggle to position themselves are represented in Table 1 below.

Figure 2. Teacher roles

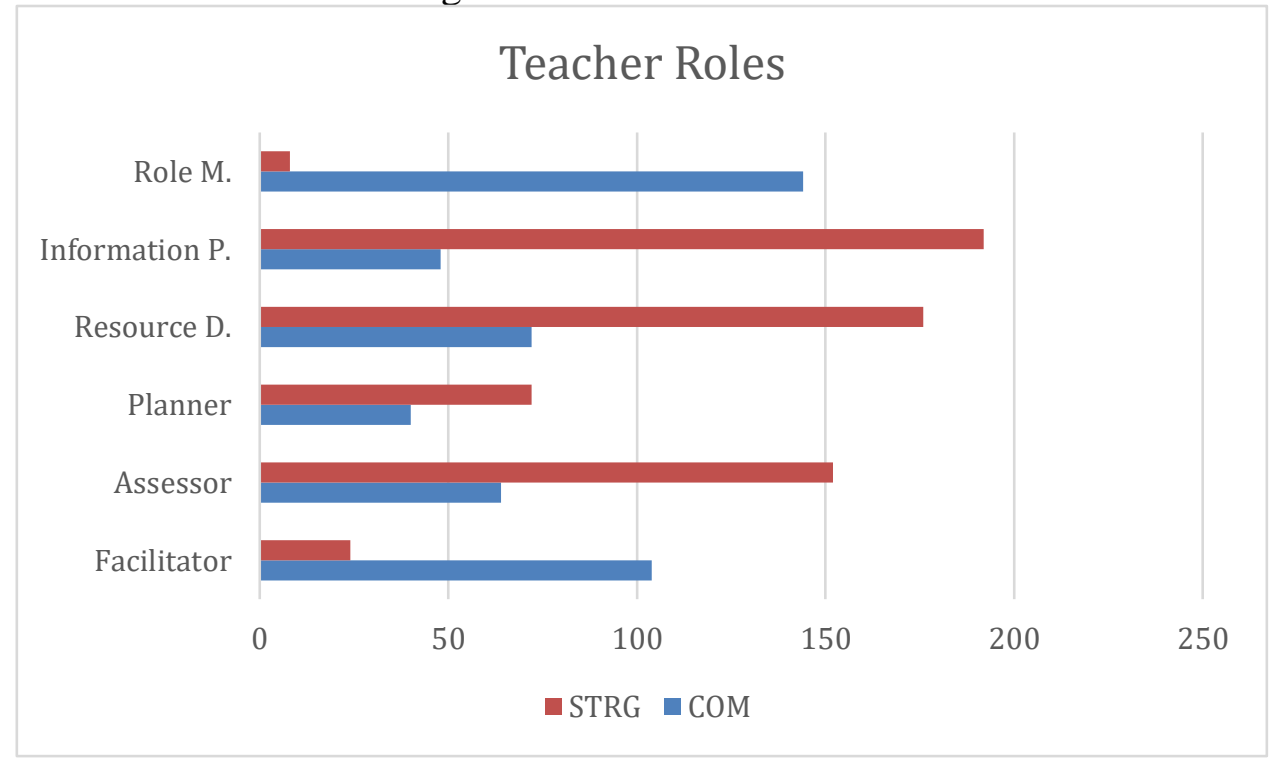

In the reflections, there were many cases where student teachers expressed concerns about not having as high a mastery of the English language as they wanted and about not being competent enough to do certain tasks. For example, one student teacher shared the following comment:

Sometimes, a student asks about meaning of lyrics of a song. The other day, one asked me about Micheal Jackson's "Smooth Criminal". The song "Annie, are you ok?". I knew the song but pretended that I had not heard it before. So I said, I would listen to it and to the next time we meet with the student I would explain the meaning. At home I 
went on Google. Read the lyrics, read about the song, some comments as well but still didn't understand. I felt embarrassed. It is hard to accept as a teacher I cannot explain to my student the meaning of a song.

In their reflections, the student teachers frequently commented that they wanted to be "a teacher with strong knowledge," described as having "an excellent command of English," "not saying 'I don't know," and "speaking native-like." One student teacher raised one of her own concerns about her English in the following comment: " $M y$ English must be perfect, and this worries me to death. I am not a native speaker and students will know that. I am doing my best to be a good teacher though."

The following comment from another student teacher illustrates the second role, resource developer, in which our ELT students said that they were struggling to position themselves:

This week I had to write a grammar test for my intermediate students on the use of past continues and past simple. I found a good fill-in activity on the Internet. In parentheses, the verbs the students had to use were given so it was not very challenging. I tried to do it myself. I couldn't decide which to use in a couple of places. I decided not to use it because I couldn't find the key on the Internet. I used a grammar book. How am I going to write tests or give answers to students when they ask me questions from a TOEFL book for example?

The teacher role of resource provider may require fulfilling a range of responsibilities at schools. To give some examples, these might include preparing instructional materials for websites or sharing articles to give practical recommendations about comprehension. In the reflections we collected from our ELT student teachers, we did not come across any references to this type of broader understanding; however, there was a heavy emphasis on the responsibility of materials design. There were various comments regarding the subject matter and discrete components of the English language along the lines of what the student teachers felt to be "advantageous," including, for example, having "good grammar knowledge" and "being a good model" with their language learning experience.

The third role our ELT student teachers commonly expressed a lack of comfort in positioning themselves was the role of assessor. There was a high level of awareness in their generalizations about what a teacher is and should be like in terms of assessment, commonly followed by their concerns. The following comments are two examples: "[t]hey (teachers) will not only teach and move on; they will also assess! I don't know how to assess speaking but I hope to get better;" "If my students say they want me to assess their English to tell them how god they are, for example in speaking, I would not know. Some students want to take IELTS and there is speaking. They want to know if they can pass it. First couple of years in teaching will be hard." Additional comments about the assessor role were also offered. The student teachers emphasized in their reflective journal entries that as assessors, their role will be crucial because it involves communicating sensitively and supportively in order to sustain students' self-esteem and confidence in learning the target language. They expressed their discomfort about having insufficient knowledge to enable them to give meaningful feedback and make corrections. However, comments such as "How can I correct students' papers when I still make mistakes in writing?" raise questions about the root of their discomfort, which could be a lack of expertise in assessment or a belief that the teacher should be the ideal language user and information provider.

In general, in relation to ELT student teacher roles, our findings indicate that student teachers frequently evaluated themselves as second language learners and criticized their proficiency in English as well as their knowledge about the English language. Comments such as "I must have a 
powerful knowledge and know as much as a native speaker" were striking since they showed how much "ownership" of English ELT student teachers believed they had in their subject matter. There were comments in reference to the institutions where they wanted to work that "many non-native English teachers are not hired by these institutions" "despite being highly qualified." These concerns could offer a potential motive as to why our ELT student teachers prioritized the mastery of knowledge in their reflections along with the teacher roles in which they were struggling to position themselves. They might want to use "their advantage" (their words) of having "remarkable linguistic knowledge, mastery of competence and performance" to resist the "pervasive ideology" (Holliday, 2006, p. $385)$ that regards native teachers as both model speakers and ideal teachers.

The findings that we reached as a result of the descriptive analysis based on the survey responses to find out whether there was a common domain of expertise (pedagogy, subject matter, and didactics) indicated that our ELT student teachers wanted to be the most confident in the subject matter domain, which was followed by didactics and pedagogy. Since our population size was small $(n=18)$, we did not set out to arrive at parametric test results indicating statistical significances. Table 2 represents teacher expertise domains the participants indicated.

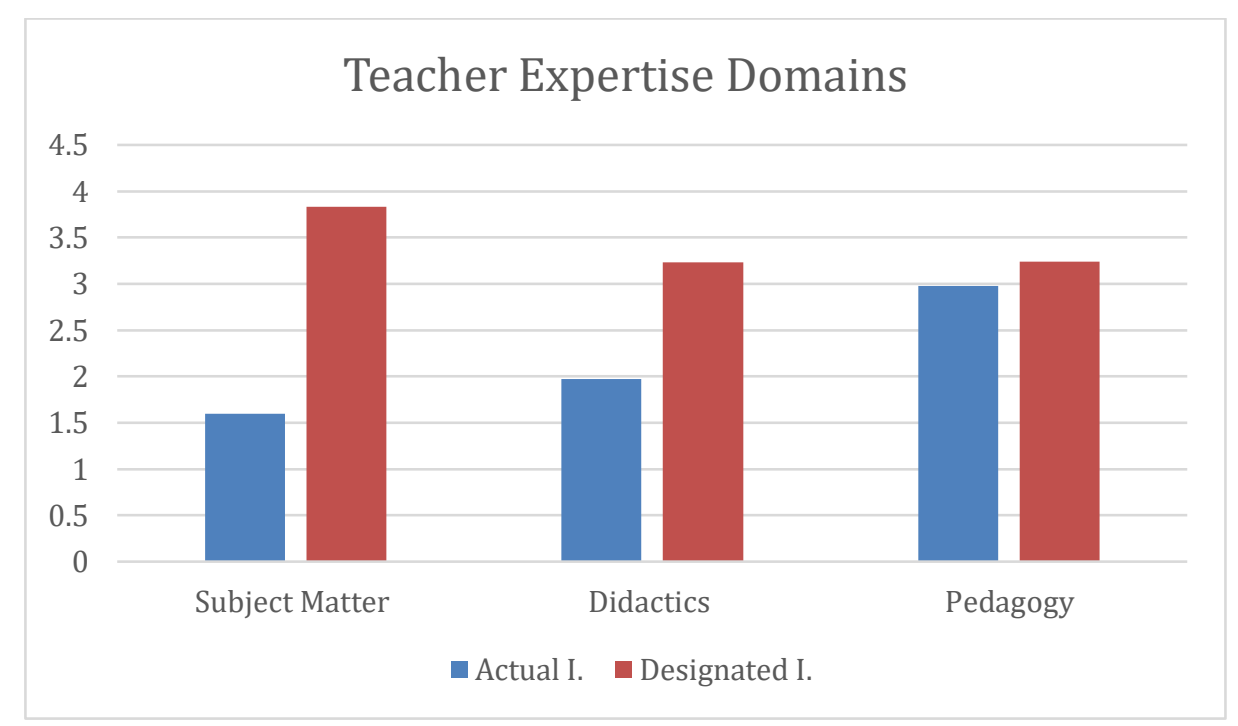

Figure 3. Teacher expertise domains

\section{DISCUSSION}

Overall, our ELT student teachers found the teacher roles of information provider, resource developer, and assessor to be the most challenging roles in which to position themselves comfortably and that they would like to develop themselves primarily and predominantly in the ELT subject matter domain. Additionally, they expressed frequent concerns about the ELT subject matter domain, commenting that they still have insufficient mastery of the knowledge about the language components of English (e.g., fluency, accents, idiomatic usages, colloquial language, etc.) and about English in terms of not making language mistakes in writing or speaking (where to use active/passive in academic writing, how to formulate non-run-on sentences, etc.). There are various references to a lack of feeling of belonging to the group of language experts that they mostly refer to as "native speakers" or people with the expertise of "near-native speakers."

We will now discuss these findings with respect to two complementary implications we arrived at. One is that ELT student teachers need more exposure to the subject 
matter, the English language, so that they can develop a sense of identity, which is positively shaped along with an increased sense of language mastery and ownership regarding the subject matter, starting early in their teacher education program. In this way, they can become more confident and more comfortable with their teacher roles, such as the ones our ELT student teachers reported that they are struggling to position themselves in. The second implication arises out of the acknowledgement, mentioned earlier in this paper, that various language ideologies are at work in explorative studies of teacher identity in ELT teacher education. Common approaches to teacher education are increasingly critiqued for their limited relationship to student teachers' needs and for their meager impact on practice (Korthagen, Loughran, \& Russel, 2006). Long ago, Tedick and Walker (1995) suggested that programs that prepare teachers for different language learning settings have concentrated on the "how" without questioning the "what" together with the "why" and the "who." Our ELT student teacher perspectives obtained through their reflections on teacher roles, with a heavy emphasis on their desire to reach the level of native speakers of English, and the domain, the subject matter of English, indicate that ELT student teachers would be happy to be exposed predominantly to the "what" in their teacher education program. Bringing on board the language ideologies at work, we suggest that our findings also imply a need to create third spaces (Bhabha, 1990; Flessner, 2014; Soja, 1996) in ELT teacher education programs so that student teachers can reimagine the ways in which they wish to construct their ELT identities through the mastery of the "what," i.e., the subject matter English language.

Nieto (2017) argues that teachers should be "sociocultural mediators" and that they should "begin by examining their own knowledge, perceptions, and biases concerning their students, and then adjusting their pedagogical practices to reflect a more equitable approach" to honor and affirm their students' sociocultural knowledge, skills, talents, and experiences (p. 9). She adds that "[o]ne way to address this issue is to actually practice becoming a sociocultural mediator, both in their teacher education and in their schools when they become teachers" (p. 9). ELT teacher education programs will need to facilitate reflective practices for (student) teachers to critically analyze language ideologies, at least with a broad consideration of monoglossic versus heteroglossic perspectives, to transform the ways in which monoglossic ideologies index certain linguistic resources to a higher sociolinguistic scale. The absence of such a critical pedagogy in ELT teacher education programs in the context of this study and elsewhere in similar contexts where English is taught more like a second language; it is possible that ELT teacher education programs could perpetuate the ideological alignment of the "native speaker fallacy" (Holliday, 2005; Phillipson, 1992). Andrews (2008) does not associate language teacher competence with the place of the teacher on a native speaker/non-native speaker (NS/NNS) continuum or ethnicity. Rather, he points out that having knowledge of the language, about the language, and about the student profile along with the ability to use these harmoniously are of paramount importance for efficient language teachers. $\mathrm{He}$ further maintains that with the development of alternative pedagogies to the hegemonic Anglo-American ELT approaches, such as English as a lingua franca, the traditional dichotomy of NS/NNS has been questioned. However, based on our findings, we argue that such academic questioning has not yet penetrated ELT teacher education programs, at least not to the extent that ELT student teachers have started to question monoglossic versus heteroglossic perspectives in their identity construction, as reflected by their responses to the teacher role and teacher expertise domains. Finally, we suggest that attempts to restructure ELT teacher education with new models and certification programs should integrate into their curricula an emphasis on teacher 
identity construction and critical pedagogy around language ideologies, with overt references to these, if possible; for instance, these programs could include course titles such as "ELT Teachers and Teacher Identity" or "Teaching Philosophy and Practices and Language Ideologies in ELT."

\section{CONCLUSION}

Teacher identity demands special interest from teacher educators and teacher education programs. It is a complex and an ambiguous concept which deserves longitudinal research. Beauchamp and Thomas (2009) state that student teachers must undergo a shift in identity as they move through teacher education programs and take on positions as teachers in today's challenging school contexts. According to Friesen and Besley (2013), student teachers rely on life experiences, which inform their early teacher identity. Therefore, teacher educators need to sensitively challenge students' pre-conceived notions of what it is to be a teacher, as students who enter teacher education programs have likely not taken the time to adequately explore the nature of the language teaching profession they will undertake. The researchers of this study will track the professional identity development of four student teachers who participated in this study as they will be working as inservice teachers as of 2019-2020 academic year. Pre-service and in-service teachers generally explore the essential elements of professional identity, defined as "the principles, intentions, characteristics and experiences by which an individual defines him or herself in a professional role" (McSweeney, 2016, p. 367), which are acquired through acting in a particular role over a period of time. Johnson (1999) examines how "reasoning teaching represents the complex ways in which teachers conceptualize, construct explanations for, and respond to the social interactions and shared meanings that exist within and among teachers, students, parents, and administrators, both inside and outside the classroom" (p. 1). Through the investigation of our research questions in our study, we have highlighted that ELT language teacher programs could integrate ELT teacher identity into their curricula with at least an overview of how language ideologies are at work in language teaching in terms of student teachers' identity and profession.

\section{REFERENCES}

Akkerman, S. F., \& P. C. Meijer. (2011). A dialogical approach to conceptualizing teacher identity. Teaching and Teacher Education, 27(2), 308-319.doi: 10.1016/j.tate.2010.08.013

Alsup, J. (2006). Teacher identity discourses. Negotiating personal and professional spaces. Mahwah, NJ: Lawrence Erlbaum.

Andrews, S. J. (2008). Teacher language awareness. In N. H. Hornberger (Ed.), Encyclopedia of language and education (Vol. 6, pp. 287298). Boston: Springer.

Arık, B. T., \& Arık, E. (2014). The role and status of English in Turkish higher education. English Today, 30(4), 510. doi:10.1017/S0266078414000339

Bailey, K. M., Curtis, A., \& Nunan, D. (2001). Pursuing professional development: The self as source. Boston: Heinle and Heinle.

Bakhtin, M. (1973). Problems of Dostoevsky's poetics, $2^{\text {nd }}$ ed. (R. W. Rotsel, Trans.). Ann Arbor, MI: Ardis. (Original work published in 1929 as Problemy tvorchestva Dostoevskogo [Problems of Dostoevsky's Art]).

Banks, J. A. (1999). Series forward. In G. R. Howard (Ed.), We can't teach what we don't know: White teachers, multiracial schools (pp. ix-xi). New York: Teachers' College Press.

Bauman, Z. (1996). From pilgrim to touristOr a short history of identity. In S. Hall \& P. du Guy (Eds.), Questions of cultural identity (pp. 18-36). 
London: Sage.

Beauchamp, C., \& Thomas, L. (2006). Imagination and reflection in teacher education: The development of professional identity from student teaching to beginning practice. In Conference Proceedings from the $4^{\text {th }}$ International Conference on Education and Imagination (pp. 1215). Vancouver, BC, Canada.

Beauchamp, C., \& Thomas, L. (2009). Understanding teacher identity: An overview of issues in the literature and implications for teacher education. Cambridge Journal of Education, 39(2), 175-189. doi: 10.1080/03057640902902252

Beijaard, D., Verloop, N., \& Vermunt, J. D. (2000). Teachers' perceptions of professional identity: An exploratory study from a personal knowledge perspective. Teaching and Teacher Education, 16(7), 749-764.

doi: 10.1016/S0742-051X(00)000238

Benwell, B., \& Stokoe, E. (2006). Discourse and identity. Edinburgh: Edinburgh University Press.

Bernard, H. R. (2011). Research methods in anthropology: Qualitative and

quantitative approaches ( $5^{\text {th }}$ ed.).

Walnut Creek, CA: AltaMira.

Bhabha, H. (1990). The other question: Difference, discrimination and the discourse of colonialism. In $\mathrm{R}$. Ferguson, M. Gever, T. T. Minh-ha, \& C. West (Eds.), Out there: Marginalization and contemporary cultures (pp. 71-87). New York: The New Museum of Contemporary Art.

Blommaert, J. (2007). Sociolinguistic scales. Intercultural Pragmatics, 4(1): 1-19.

Borich, G. D. (1999). Dimensions of self that influence effective teaching. In R. P. Lipka, \& T. M. Brinthaupt (Eds.), The role of self in teacher development (pp. 92-117). Albany, NY: SUNY Press.

Bukor, E. (2015). Exploring teacher identity from a holistic perspective:
Reconstructing and reconnecting personal and professional selves. Teachers and Teaching, 21(3), 305327.

doi: $10.1080 / 13540602.2014 .953818$

Butler, J. (1990). Gender trouble: Feminism and the subversion of identity. New York: Routledge.

Canagarajah, S. (2013). Translingual practice: Global Englishes and cosmopolitan relations. New York, NY: Routledge.

Cattley, G. (2007). Emergence of the professional identity for the preservice teacher. The International Education Journal, 8(2), 337-347. Retrieved from http://files.eric.ed.gov/fulltext/EJ834 271.pdf

Connelly, F. M., \& Clandinin, D. J. (1988).

Teachers as curriculum planners:

Narratives of experience. New York:

Teachers' College Press.

Creswell, J. W. (2012). Qualitative inquiry and research design: Choosing among five approaches ( $3^{\text {rd }}$ ed.). Thousand Oaks, CA: Sage.

Davies, B., \& Harré, R. (1990). Positionings: The discursive production of selves. In B. Davies (Ed.), A body of writing (pp. 87-106). New York, NY: AltaMira.

Day, C., Kington, A., Stobart, G., \& Sammons, P. (2006). The personal and professional selves of teachers: Stable and unstable identities. British Educational Research Journal, 32(4), 601-616. doi: 10.1080/01411920600775316

Dewey, J. (1933). How we think: A restatement of the relation of reflective thinking to the educative process. Boston: D. C. Heath and Co.

Dörnyei, Z. (2009). The L2 motivational self system. In Z. Dörnyei, \& E. Ushioda (Eds.), Motivation, language identity and the L2 self (pp. 9-42). Bristol: Multilingual Matters.

Fielding, N. (2008). The role of computerassisted qualitative data analysis: 
Impact on emergent methods in qualitative research. In S. N. HesseBiber, \& P. Leavy (Eds.), Handbook of emergent methods (pp. 675-95). New York: Guilford.

Flessner, R. (2014). Revisiting reflection: Utilizing third spaces in teacher education. The Educational Forum, $78(3), 231-247$.

Freese, A. R. (2006). Reframing one's teaching: Discovering our teacher selves through reflection and inquiry. Teaching and Teacher Education, 22(1), 100-119. doi: 10.1016/j.tate.2005.07.003

Friesen, M. D., \& Besley, S. C. (2013) Teacher identity development in the first year of teacher education: A developmental and social psychological perspective. Teaching and Teacher Education, 36, 23-32. doi: 10.1016/j.tate.2013.06.005

Garcia, O. (2009). Bilingual education in the 21 st century: A global perspective. Malden, MA: Wiley-Blackwell.

Gee, J. P. (2000). Identity as an analytic lens for research in education. Review of Research in Education, 25, 99-125. doi: 10.2307/1167322

Gelter, H. (2003). Why is reflective thinking uncommon? Reflective Practice, 4(3), 337-344. doi: $10.1080 / 1462394032000112237$

Gergen, K. J. (1991). The saturated self. Dilemmas of identity in contemporary life. New York: Basic Books.

Hamachek, D. (1999) Effective teachers: What they do, how they do it, and the importance of self-knowledge. In R. Lipka, \& T. Brinthaupt (Eds.), The role of self in teacher development (pp. 189-224). Albany: SUNY Press.

Harden, R. M., \& Crosby, J. R. (2000). The good teacher is more than a lecturer: The twelve roles of the teacher. Medical Teacher, 22(4), 334-347.

Hermans, H. J., Kempen, H. J., \& Van Loon, R. J. (1992). The dialogical self: Beyond individualism and rationalism. American Psychologist, 47(1), 23.

doi: $10.1037 / 0003-066 X .47 .1 .23$

Higgins, E. T. (1987). Self-discrepancy: A theory relating self and affect. Psychological Review, 94(3), 319340. doi: 10.1037/0033295X.94.3.319

Higgins, E. T. (1998). Promotion and prevention: Regulatory focus as a motivational principle. Advances in Experimental Social Psychology, 30, $1-46$.

doi: 10.1016/S0065-2601(08)603810

Holland, D., \& Lave, J. (Eds.) (2001). History in person: Enduring struggles, contentious practice, intimate identities. Santa Fe, NM: School of American Research Press.

Holliday, A. (2005). The struggle to teach English as an international language. Oxford: Oxford University Press.

Irvine, J. T. \& Gal, S. (2000). Language ideology and linguistic differentiation. In P.

Kroskrity (Ed.), Regimes of language. (pp. 35-83). Santa Fe, NM: School of

American Research Press.

James, W. (1890). The principles of psychology (Vol. 1). London: Macmillan.

Johnson, K. E. (1999). Understanding language teaching: Reasoning in action. Boston: Heinle and Heinle.

König, J., Blömeke, S., Paine, L., Schmidt, W. H., \& Hsieh, F. J. (2011). General pedagogical knowledge of future middle school teachers: On the complex ecology of teacher education in the United States, Germany, and Taiwan. Journal of Teacher Education, 62(2), 188-201. doi: $10.1177 / 0022487110388664$

Korthagen, F., Loughran, J., \& Russell, T. (2006). Developing fundamental principles for teacher education programs and practices. Teaching and Teacher Education, 22(8), 10201041. doi: 10.1016/j.tate.2006.04.022 
La Pointe, K. (2010). Narrating career, positioning identity: Career identity as a narrative practice. Journal of Vocational Behavior, 77(1), 1-9.

Ladson-Billings, G. (1995). Multicultural teacher education: Research, practice, and policy. In J. Banks (Ed.), Handbook for research on multicultural education (pp. 747759). New York: MacMillan.

Lamote, C., \& Engels, N. (2010). The development of student teachers' professional identity. European Journal of Teacher Education, 33(1), 3-18.

doi: 10.1080/02619760903457735

Lauriala, A., \& Kukkonen, M. (2005). Teacher and student identities as situated cognitions. In P. Denicolo, \& M. Kompf (Eds.), Connecting policy and practice: Challenges for teaching and learning in schools and universities (pp. 199-208). Oxford: Routledge.

Lipka, R. P., \& Brinthaupt, T. M. (Eds.) (1999). The role of self in teacher development. Albany, NY: SUNY Press.

Löfström, E., Poom-Valickis, K., Hannula, S. M., \& Mathews, S. R. (2010). Supporting emerging teacher identities: Can we identify teacher potential among students? European Journal of Teacher Education, 33(2), 167-184.

doi: $10.1080 / 02619761003631831$

McSweeney, F. (2016). Supervision of students in social care education: Practice teachers' views of their role. Social Work Education, 36(1), 1-22. doi: 10.1080/02615479.2016.1249837

Mortimer, S. K. (2016). A potentially heteroglossic policy becomes monoglossic in context: An ethnographic analysis of Paraguayan bilingual education policy. Anthropology \& Education Quarterly, 47(4), 349-365.
Nieto, S. (2017). On becoming sociocultural mediators. Teaching Works working paper. University of Michigan.

Ölçme, Seçme ve Yerleştirme Merkezi. (2013). Tablo 4. Merkezi yerleştirme ile öğrenci alan yükseköğretim lisans programları [Table 4. Central placement and programs that accept post-graduate students]. Retrieved from

http://dokuman.osym.gov.tr/pdfdoku man/2013/OSYS/Tablo4.pdf

Olsen, B. (2008). How reasons for entry into the profession illuminate teacher identity development. Teacher Education Quarterly, Summer, 2340. Retrieved from http://teqjournal.org/Back\%20Issues/ Volume\%2035/VOL35\%20PDFS/35 _3/07olsen-35_3.pdf

Park, G. (2012). "I am never afraid of being recognized as an NNES:" One teacher's journey in claiming and embracing her nonnative-speaker identity. TESOL Quarterly, 46(1), 127-151.

Phillipson, R. (1992). Linguistic imperialism. Oxford: Oxford University Press.

Piller, I. (2015). Language ideologies. In K. Tracy, C. Ilie, \& T. Sandel (Eds.), The international encyclopedia of language and social interaction (Vol. 2, pp. 917-927). West Sussex: Wiley-Blackwell.

Riopel, M. C. (2006). Apprendre à enseigner: Une identité professionnelle à developer [Learning to teach: Developing a professional identity]. Sainte-Foy, Quebec: Les Presses de l'Université Laval.

Rodgers, C., \& Scott, K. (2008). The development of the personal self and professional identity in learning to teach. In M. Cochran-Smith, S. Feiman-Nemser, D. J. McIntyre, \& K. E. Demers (Eds.), Handbook of research on teacher education: Enduring questions and changing contexts (pp. 732-755). New York: 
Nafiye Cigdem Aktekin, \& Hatice Celebi, ELT Student Teacher Identity Construction:...

Routledge.

Roth, W. M. (2004). Identity as dialectic: $\mathrm{Re} /$ making self in urban schooling. Mind, Culture, and Activity, 11(1), 48-69. doi: 10.1207/s15327884mca1101_4

Rots, I., Aelterman, A., Vlerick, P., \& Vermeulen, K. (2007). Teacher education, graduates' teaching commitment and entrance into the teaching profession. Teaching and Teacher Education, 23(5), 543-56. doi: 10.1016/j.tate.2007.01.012

Sachs, J. (2005). Teacher education and the development of professional identity: Learning to be a teacher. In P. Denicolo, \& M. Compf (Eds.), Connecting policy and practice: Challenges for teaching and learning in schools and universities (pp. 521). Oxford: Routledge.

Saldaña, J. (2013). The coding manual for qualitative researchers. London: SAGE.

Schön, D. A. (1983). The reflective practitioner: How professionals think in action. New York: Basic Books.

Sfard, A., \& Prusak, A. (2005). Telling identities: In search of an analytic tool for investigating learning as a culturally shaped activity. Educational Researcher, 34(4), 1422. doi: 10.3102/0013189X034004014

Skutnabb-Kangas, T. (1981). Tvåspråkighet [Bilingualism]. Lund: Liber Läromedel.

Soja, E. W. (1996). Thirdspace: Journeys to Los Angeles and other real-andimagined places. Malden, MA: Blackwell.

Stenberg, K., Karlsson, L., Pitkaniemi, H., \& Maaranen, K. (2014). Beginning student teachers' teacher identities based on their practical theories. European Journal of Teacher Education, 37(2), 204-219. doi: 10.1080/02619768.2014.882309

Tedick, D. J., \& Walker, C. L. (1995). From theory to practice: How do we prepare teachers for second language classrooms? Foreign Language Annals, 28(4), 499-517. doi: 10.1111/j.1944-9720.1995.tb00823.x Thomas, L., \& Beauchamp, C. (2007). Learning to live well as teachers in a changing world: Insights into developing a professional identity in teacher education. The Journal of Educational Thought (JET)/Revue de la Pensée Educative, 41(3), 229-243. Retrieved from http://www.jstor.org/stable/2376552 0 ?seq=1\#page_scan_tab_contents

van Langenhove, L., \& Harré, R. (1999). Introducing positioning theory. In L. van Langenhove, \& R. Harré (Eds.), Positioning theory: Moral contexts of intentional action. Oxford: Basil Blackwell.

Van Manen, M. (1995). On the epistemology of reflective practice. Teachers and Teaching: Theory and Practice, 1(1), 33-50.

Varghese, M., Morgan, B., Johnston, B., \& Johnson, K. A. (2005). Theorizing language teacher identity: Three perspectives and beyond. Journal of Language, Identity \& Education, 4(1), 21-44. doi: 10.1207/s15327701jlie0401_2

Vetter, A., Hartman, S. V., \& Reynolds, J. M. (2016). Confronting unsuccessful practices: Repositioning teacher identities in English education. Teaching Education, 27(3), 305-326. doi:

10.1080/10476210.2016.1145203

Voss, T., Kunter, M., \& Baumert, J. (2011). Assessing teacher candidates' general pedagogical/psychological knowledg e: Test construction and validation. Journal of Educational Psychology, 103(4), 952-969. doi: $10.1037 / \mathrm{a} 0025125$

Vygotsky, L. S. (1998). Infancy. In Rieber R. W. (Ed.), The collected works of L. S. Vygotsky (Vol. 5, pp. 207-241). New York: Plenum.

Yowell, C. M. (2002). Dreams of the future: The pursuit of education and career 
International Journal of language Education, Vol. 4 No.1, March 2020 pp. 113-128

possible selves among ninth grade Latino youth. Applied Developmental Science, $\quad 6(2)$, $62-$ 72. doi:10.1207/S1532480XADS060 2_2

Zembylas, M. (2003). Interrogating "teacher identity:" Emotion, resistance and self-formation. Educational Theory, 53(1), 107-127.

doi: 10.1111/j.17415446.2003.00107 .X 